\title{
Recent Changes in Soil Total Phosphorus in the Everglades: Water Conservation Area 3
}

\author{
Gregory L. Bruland • Todd Z. Osborne • K. R. Reddy • \\ Sabine Grunwald • Susan Newman • William F. DeBusk
}

Received: 7 December 2005 / Accepted: 28 June 2006 / Published online: 21 October 2006

(C) Springer Science + Business Media B.V. 2006

\begin{abstract}
We assessed recent changes in the distribution of soil total phosphorus (TP) in Water Conservation Area 3 (WCA-3) of the Everglades. Soil cores were collected in 1992 and 2003 at 176 sites. To reflect hydrologic boundaries within the system, WCA-3 was divided into three zones (3AN, 3AS, and $3 \mathrm{~B})$. Total $\mathrm{P}$ was mapped on both a mass (TPm) and a volumetric basis (TPv) to determine if spatial distributions varied depending on the choice of units.
\end{abstract}

G. L. Bruland $(\bowtie) \cdot$ T. Z. Osborne

K. R. Reddy $\cdot$ S. Grunwald

Institute for Food and Agricultural Sciences,

Soil and Water Science Department, University of Florida,

2169 McCarty Hall, P.O. Box 110290,

Gainesville, FL, USA

e-mail: bruland@hawaii.edu

S. Newman

Everglades Division,

South Florida Water Management District,

P.O. Box 24680, West Palm Beach, FL, USA

\section{W. F. DeBusk}

Escambia County Engineering Department,

Water Quality Section,

1190 W. Leonard Street,

Pensacola, FL, USA

Present address:

G. L. Bruland

Natural Resources and Environmental Management

Department, University of Hawai'i at Manoa,

1910 East-West Rd.,

Honolulu, HI, USA
Interpolated maps for both years showed that the highest levels of TPm were located in 3AN and in boundary areas of all zones that received surface water inputs of $\mathrm{P}$ from canals. Increases in TPm were greatest in central $3 \mathrm{AN}$ in an area adjacent to the Miami Canal that received inputs from a water control structure. Interpolated maps for $\mathrm{TPv}$ illustrated that a hotspot present in 1992 had disappeared by 2003. The highest levels of TPv in 2003 were located in northwestern $3 \mathrm{AN}$, a region of WCA-3 that has been chronically overdrained and burned in 1999. From 1992 to 2003, increases in TPm were observed for $53 \%$ of the area of WCA3 , while only $16 \%$ of WCA-3 exhibited increases in TPv. In 1992, approximately $21 \%$ of WCA-3 had $\mathrm{TPm}$ concentrations in the $0-10 \mathrm{~cm}$ layer $>500 \mathrm{mg}$ $\mathrm{kg}^{-1}$, indicating $\mathrm{P}$ enrichment beyond historic levels. Eleven years later, $30 \%$ of the area of WCA-3 had $\mathrm{TPm}>500 \mathrm{mg} \mathrm{kg}^{-1}$. This indicated that during this period, the area of WCA-3 with enriched TPm concentrations increased about one $\%$ year $^{-1}$.

Keywords Change map · Everglades · Florida · GIS . Total phosphorus $\cdot$ Soil $\cdot$ Spatial variability $\cdot$ Wetland

\section{Introduction}

Agricultural activities to the north and urbanization to the east have increased nutrient loading, especially in the form of $\mathrm{P}$, to the Everglades wetlands (Noe, 
Childers, \& Jones, 2001; McCormick et al., 2001). For example, Davis (1994) estimated that, as a result of increased nutrient loading from drained agricultural lands, annual phosphorus $(\mathrm{P})$ inputs to the Water Conservation Areas (WCAs) increased from historic levels of approximately 129 metric tons (mt) to levels of approximately $376 \mathrm{mt}$. Changes in hydrology combined with increased nutrient loading have not only led to a rapid expansion of Typha domingensis (cattail) in areas that receive water directly from the Everglades Agricultural Area (EAA) (Newman, Grace, \& Koebel, 1996; Noe et al., 2001), but also to significant changes in ecosystem structure and function (Davis, 1991; Koch \& Reddy, 1992; Drake et al., 1996; Newman et al., 1998; McCormick \& Stevenson, 1998).

Unlike the nutrient concentrations in the water column that are highly variable in time (Reddy, White, Wright, \& Chua, 1999), nutrient concentrations in Everglades soils are integrators of long-term environmental conditions (DeBusk, Newman, \& Reddy, 1994; Craft \& Richardson, 1997; Richardson, Ferrell, \& Vaithiyanathan, 1999; King, Richardson, Urban, \& Romanowicz, 2004). Furthermore, nutrient inputs to Everglades wetlands are primarily stored in the peat, as the vegetation represents only a shortterm nutrient sink (Craft \& Richardson, 1993a; Newman et al., 1997). Thus, the spatial distribution of soil nutrients can be used as a means of assessing long-term nutrient impacts to this system (Newman et al., 1997). Correspondingly, soils are an ideal ecosystem component for assessing the status of WCA-3 prior to initiation of the Comprehensive Everglades Restoration Plan (CERP) activities. As WCA-3 will be the centerpiece of future CERP activities (U.S. Department of the Interior, 2005; U.S. Army Corps of Engineers, 2005), it is essential to quantify the recent changes in the spatial distributions of TP in WCA-3. Documenting such changes will provide critical feedback for the future management and restoration of this area. This will facilitate the targeting of areas that have been subjected to the greatest increases in soil TP for restoration and management.

In this study we utilized two spatially-explicit datasets collected in a subtropical Everglades wetland, Water Conservation Area 3 (WCA-3), to produce continuous maps of the changes in the spatial distributions of soil total phosphorus (TP) over time.
Specifically, we created interpolated raster maps of the distribution of soil TP in WCA-3 in 1992 and 2003. We utilized map algebra functions within a GIS to calculate change in soil TP maps for WCA-3 over this 11 year period. Such "change maps" express the data not in terms of simple concentrations but in terms of change in concentrations from 1992 to 2003 . While GIS-based change maps have been produced for soil properties such as total carbon (Van Meirvenne, Pannier, Hofman, \& Louwagie, 1996; Sleutel et al., 2003; Zhang \& McGrath, 2004), to our knowledge, this is the first time change maps have been produced for TP in a wetland ecosystem. Mapping space-time trajectories of soil properties has applicability not only for Everglades wetlands, but also for various other types of ecosystems. These types of maps are useful for tracking the development of restored ecosystems, or investigating changes in ecosystem properties over time.

In addition to creating change maps for TP, a secondary goal of this research was to quantify differences in TP data expressed on a mass/ concentration versus a volumetric basis. Scientists often wrestle with the choice of units when dealing with soil data. In some cases it may be more appropriate to express data on a concentration basis (Bruland \& Richardson, 2004), while in other cases it may be more appropriate to express data on a volumetric basis (Smith, Newman, Garrett, \& Leeds, 2001). Using concentration units avoids the problem of multiplying precise numbers derived from laboratory analyses by more uncertain bulk density (BD) data (Bruland, Grunwald, Osborne, Reddy, \& Newman, 2006). However, volumetric data perhaps allows interpretation from more of an ecological perspective as microbes and plant root systems occupy soil in three-dimensional space rather than by weight (Smith et al., 2001). Volumetric data also provide us with information about the storage of a soil nutrient across different soil horizons or even different ecosystem types. In many cases there is no one correct choice for the units of expression and it may be appropriate to report results on both a concentration and volumetric basis, as each will provide different insights into the question at hand. Thus, the objective of this study was to utilize geostatistics and GIS map algebra techniques to quantify the recent changes (1992-2003) in the spatial distribution of TP on both a concentration and a volumetric basis across 
three zones of Water Conservation Area 3 (3AN, $3 \mathrm{AS}$, and $3 \mathrm{~B})$.

\section{Materials and Methods}

\subsection{Study area}

The surface hydrology of WCA-3 is controlled by a system of levees and water control structures (WCS) located along the perimeter and inside the area. In 1962, WCA-3 was divided into two hydrologic units, WCA-3A (199,480 ha) and WCA-3B (39,830 ha), by the construction of two interior levees (L-67A and L-67C) to reduce water losses due to levee seepage (Reddy, Wang, DeBusk, Fisher, \& Newman, 1998). As Interstate 75 (Alligator Alley) bisects WCA-3A in an east-west direction, we further divided WCA-3A into two zones, 3AN (the 72,160 ha area to the north of Interstate 75), and $3 \mathrm{AS}$ (the 127,320 ha area south of I-75) (Figure 1). About 60\% of the hydrologic inputs to WCA-3 are from precipitation, while $17 \%$ enter the area from the S-11A, S-11B, and S-11C structures (South Florida Water Management District, 1992) (Figure 1). In general, $3 \mathrm{AN}$ has been overdrained by these hydrologic modifications, while $3 \mathrm{AS}$ has been subjected to prolonged flooding in the southern portion (David, 1996).

Water Conservation Area 3 is also unique in that it is the heart of the "ridge and slough" portion of the Everglades landscape (Childers et al., 2003). In the more pristine southern sections of WCA-3, strands of Cladium jamaicense (sawgrass) ridges and tree islands alternate with deeper sloughs in an orientation parallel to the direction of historical water flow. However, changes in hydrology and increased nutrient loading have resulted in the degradation of the "ridge and slough" landscape in the northern areas of WCA-3 (Sklar et al., 2001).

The majority of the soils in WCA-3 are Histosols, including Everglades peats and Loxahatchee peats (Gleason et al., 1974). Everglades peats develop on topographically higher areas and are comprised of decomposing Cladium and other plant tissue. These soils are typically brown to black with minimal mineral content. Loxahatchee peats develop in topographically low areas and are composed of remains of the roots and rhizomes of Nymphea odorata (white water lilly). Mixed marl peats are present in the western margin of
3AS that have derived from the underlying limestone (Brown, Stone, \& Carlisle, 1991).

\subsection{Field sampling}

An irregular grid sampling design was used to collect 176 soil samples from WCA-3 in 1992 (Reddy, Wang, DeBusk, \& Newman, 1994) (Figure 1). Grid spacing was finer in the northern and eastern sections of WCA-3 that were expected to be impacted by nutrient inputs and coarser in the more pristine southern and western sections. During the resampling in 2003, 388 soil cores were collected from WCA-3 with a stratified random sampling design (Bruland et al., 2006). Predetermined sampling sites were located in the field with a global positioning system mounted to a helicopter. Sampling during both dates was constrained to the marsh areas and excluded tree islands. To make a comparison between the two sampling events, bias due to different sampling densities and geospatial designs had to be minimized. Thus, we chose to constrain the analysis to the 176 samples from the 2003 sampling that were located closest to the samples collected in 1992 (Figure 1).

In 1992 soil cores were collected by driving a $10 \mathrm{~cm}$ (inner diameter) thin-walled stainless-steel coring tube to a depth of $20 \mathrm{~cm}$ beneath the floc/soil surface. The cores were sectioned in the field into 0 $10 \mathrm{~cm}$ and 10-20 $\mathrm{cm}$ layers (Figure 2). For this sampling, floc material was included in the $0-10 \mathrm{~cm}$ layer. In 2003, floc material was separated from the upper $0-10 \mathrm{~cm}$ and $10-20 \mathrm{~cm}$ layers. To enable a comparison between the two samplings, the 1992 sampling protocol was adopted as a reference. The 2003 soil profiles were reconstructed to match the 1992 soil profiles (Figure 2). The 2003 data were reconstructed by weighting by the depth and bulk density of each layer in the following formula:

$$
\begin{aligned}
\mathrm{TPm}_{03 \mathrm{ab}}= & {\left[\left(\mathrm{D}_{\mathrm{a}} * \mathrm{BD}_{\mathrm{a}} * \mathrm{TPm}_{\mathrm{a}}\right)\right.} \\
& +\left(\mathrm{D}_{\mathrm{b}} * \mathrm{BD}_{\mathrm{b}} * \mathrm{TPm}_{\mathrm{b}}\right] /\left(10 * \mathrm{BD}_{\mathrm{ab}}\right)
\end{aligned}
$$

where $\mathrm{TPm}_{03 \mathrm{ab}}=$ reconstructed TP in topsoil for 2003 in $\mu \mathrm{g} \mathrm{g}^{-1}, \mathrm{D}_{\mathrm{a}}=$ depth of floc layer (a) in $\mathrm{cm}, \mathrm{BD}_{\mathrm{a}}=$ bulk density of floc layer (a) in $\mathrm{g} \mathrm{cm}^{-3}, \mathrm{TPm}_{\mathrm{a}}=\mathrm{TP}$ concentration of floc layer (a) in $\mu \mathrm{g} \mathrm{g}^{-1}, \mathrm{D}_{\mathrm{b}}=$ depth of upper $0-10 \mathrm{~cm}$ layer (b) in $\mathrm{cm}, \mathrm{BD}_{\mathrm{b}}=$ bulk density of upper $0-10 \mathrm{~cm}$ layer (b) in $\mathrm{g} \mathrm{cm}^{-3}, \mathrm{TPm}_{\mathrm{b}}=\mathrm{TP}$ concentration of upper $0-10 \mathrm{~cm}$ layer (b) in $\mu \mathrm{g} \mathrm{g}^{-1}$, 


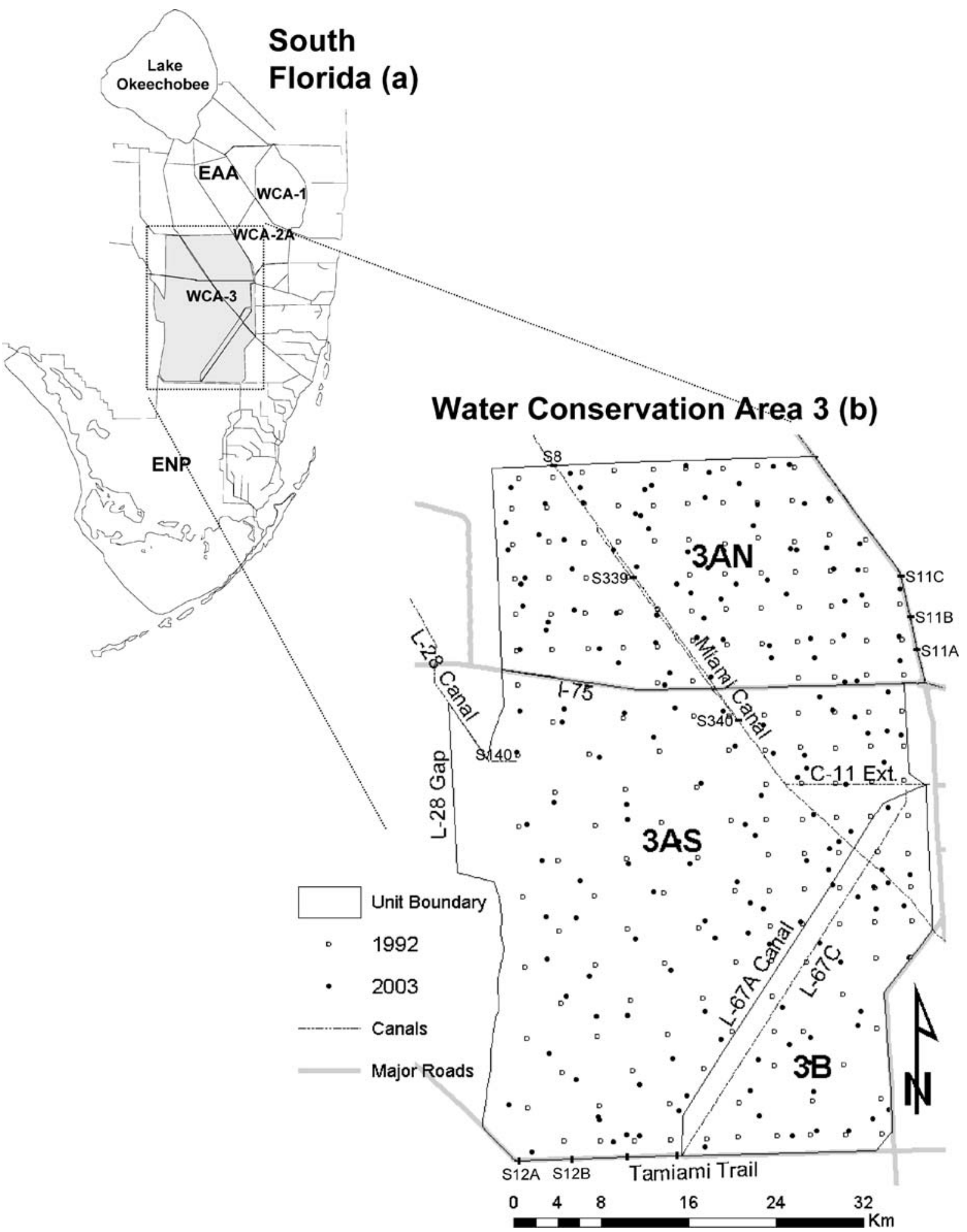

Figure 1 Maps of (a) South Florida and (b) WCA-3 with the locations of the unit boundaries, canals, roads, water control structures, and the sites from the 1992 sampling and the 2003 sampling events. 
Figure 2 Diagram of the soil coring schemes used in 1992 and 2003, as well as the reconstruction method used to modify the 2003 sampling to match the sampling from 1992.

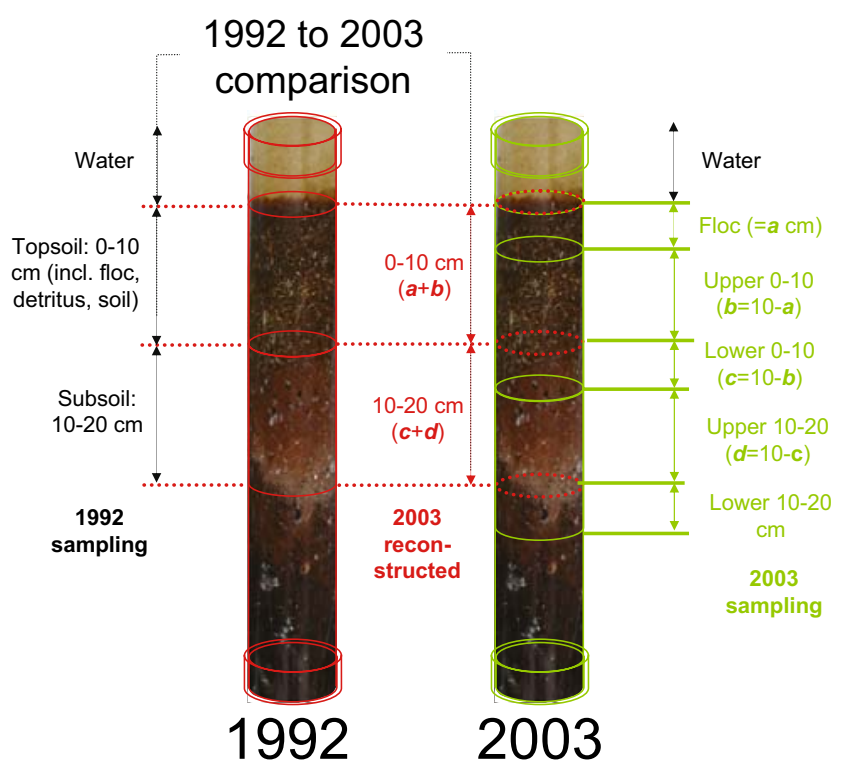

and $\mathrm{BD}_{\mathrm{ab}}=$ depth weighted $\mathrm{BD}$ for the reconstructed $0-10 \mathrm{~cm}$ layer $=\left\{\left[\left(\mathrm{D}_{\mathrm{a}} * \mathrm{BD}_{\mathrm{a}}\right)+\left(\mathrm{D}_{\mathrm{b}} * \mathrm{BD}_{\mathrm{b}}\right)\right] /(10 \mathrm{~cm})\right\}$. The subsurface layer was reconstructed in a similar manner:

$$
\begin{aligned}
\mathrm{TPm}_{03 \mathrm{~cd}}= & {\left[\left(\mathrm{D}_{\mathrm{c}} * \mathrm{BD}_{\mathrm{c}} * \mathrm{TPm}_{\mathrm{c}}\right)\right.} \\
& \left.+\left(\mathrm{D}_{\mathrm{d}} * \mathrm{BD}_{\mathrm{d}} * \mathrm{TPm}_{\mathrm{d}}\right)\right] /\left(10 * \mathrm{BD}_{\mathrm{cd}}\right)
\end{aligned}
$$

where $\mathrm{TPm}_{03 \mathrm{~cd}}=$ reconstructed $\mathrm{TP}$ in subsurface for 2003 in $\mu \mathrm{g} \mathrm{g}^{-1}, \mathrm{D}_{\mathrm{c}}=$ depth of lower 0-10 cm layer (c) in $\mathrm{cm}, \mathrm{BD}_{\mathrm{c}}=$ bulk density of lower $0-10 \mathrm{~cm}$ layer $(\mathrm{c})$ in $\mathrm{g} \mathrm{cm}^{-3}, \mathrm{TPm}_{\mathrm{c}}=$ total P concentration of lower 0 $10 \mathrm{~cm}$ layer (c) in $\mu \mathrm{g} \mathrm{g}^{-1}, \mathrm{D}_{\mathrm{d}}=$ depth of upper 10 $20 \mathrm{~cm}$ layer (d) in $\mathrm{cm}, \mathrm{BD}_{\mathrm{d}}=$ bulk density of upper 10-20 cm layer (d) in $\mathrm{g} \mathrm{cm}^{-3}, \mathrm{TPm}_{\mathrm{d}}=$ total $\mathrm{P}$ concentration of upper 10-20 cm layer (d) in $\mu \mathrm{g} \mathrm{g}^{-1}$, and $\mathrm{BD}_{\mathrm{cd}}=$ depth weighted $\mathrm{BD}$ for the reconstructed $10-20 \mathrm{~cm}$ layer $=\left\{\left[\left(\mathrm{D}_{\mathrm{c}} * \mathrm{BD}_{\mathrm{c}}\right)+\left(\mathrm{D}_{\mathrm{d}} * \mathrm{BD}_{\mathrm{d}}\right)\right] /(10 \mathrm{~cm})\right\}$. All statistical and geostatistical analyses were calculated on the 1992 and reconstructed 2003 data. The 1992 and reconstructed 2003 concentration datasets $\left(\mu \mathrm{g} \mathrm{g}^{-1}\right)$ were converted to volumetric units $\left(\mu \mathrm{g} \mathrm{cm}^{-3}\right)$ by multiplying by the $\mathrm{BD}$ calculated for each individual soil core increment.

Triplicate soil cores were collected during each sampling event from sample points that were separated by short distances $(<1 \mathrm{~m})$. These triplicate samples were useful in assessing error associated with the field sampling, laboratory analyses, and reconstruction of the data. Four sets of triplicate samples were collected from each layer in the 1992 sampling (Reddy et al., 1994), while from the reduced 2003 dataset, 9 sets of triplicates were collected from the $0-10 \mathrm{~cm}$ layer and 8 sets were collected from the $10-20 \mathrm{~cm}$ layer. The average coefficients of variation $(\mathrm{CV}=\mathrm{SD} /$ Mean $*$ 100) for the $\mathrm{BD}$ triplicates from the $0-10$ and $10-20 \mathrm{~cm}$ layers in 1992 were 12.3 and $24.3 \%$, respectively. By comparison, the average CVs for the reconstructed $\mathrm{BD}$ triplicates in the $0-10$ and $10-20 \mathrm{~cm}$ layers in 2003 were 17.1 and $10.1 \%$, respectively. The average CVs for the TP triplicates from the $0-10$ and $10-20 \mathrm{~cm}$ layers in 1992 were 9.1 and $21.0 \%$, while the average CVs for the reconstructed TP triplicates in the $0-10$ and $10-20 \mathrm{~cm}$ layers in 2003 were 12.2 and $18.3 \%$. This indicated that $\mathrm{CVs}$ from the reconstructed triplicate data were comparable to CVs from the 1992 data, and that the reconstruction technique itself did not introduce greater error or uncertainty in the 2003 reconstructed dataset.

\subsection{Laboratory analyses}

The soil samples collected in 1992 and 2003 were analyzed at the University of Florida Wetland Biogeochemistry Laboratory (WBL) for bulk density (BD) and TP. A subsample of wet soil was dried at $70^{\circ} \mathrm{C}$ for $72 \mathrm{~h}$ to determine dry weight and water content. The $\mathrm{BD}$ was determined by calculating the 
dry weight of the sample and dividing it by the volume of the corer. Total $\mathrm{P}$ was quantified by dry ashing (Anderson, 1976) followed by an automated colorimetric procedure (U.S. Environmental Protection Agency, 1993, Method 365.1).

\subsection{Geostatistical analyses}

To avoid the bias of using different interpolation methods for the 1992 and 2003 datasets, we needed to choose an interpolation technique that would perform well for both dates. Semivariograms, which quantify the spatial dissimilarity as a function of the distance between paired samples, derived for BD and TP in 1992 and 2003 showed moderate to weak spatial autocorrelation. A number of semivariograms also exhibited a high nugget effect, indicating that there was uncertainty in the estimation of fine-scale variability. The lack of structure in the empirical semivariance values in combination with the high nugget values indicated that ordinary kriging, a standard geostatistical interpolation technique, would not be appropriate for this study. Instead, we decided to employ completely regularized splines as the common interpolation method. Unlike kriging, splines make no assumptions about the distributions of the data to be mapped. They are deterministic interpolators that provide predicted surfaces that are comparable to kriging. However, they do not quantify the underlying spatial autocorrelation structure, making them less flexible and more automatic than kriging. The splines were created with ArcGIS software (Environmental Systems Research Institute, Redlands, CA). The spatial resolution of the spline maps was $100 \times 100 \mathrm{~m}$.

To map the uncertainty of estimated edaphic properties and change values across the study area was important to distinguish low uncertainty areas with higher confidence in estimations and vice versa. Since the statistical measures above evaluate the overall interpolation quality we derived the uncertainty values based on Euclidean distances. The rationale underlying the uncertainty assessment was that the uncertainty was lower when an unsampled site was located close to an observation site; whereas the uncertainty was higher when an unsampled site was located far away from an observation site. Standardized uncertainty values scaled from zero to one were derived by normalization of the maximum distance identified between sampled and unsampled locations. Our approach is formalized in Equation (3) and was implemented in ArcGIS.

$h(s, u)=\frac{s_{x, y}-u_{x, y}}{d_{\max }}$

where

$h(s, u)$ Euclidian distance in meters between sample location and an unsampled location

$s_{x, y} \quad$ Sample location identified using $x$ and $y$ coordinates (Easting and Northing)

$u_{x, y} \quad$ Unsampled location identified using $x$ and $y$ coordinates

$d_{\max }$ Maximum distance in meters between $s_{x, y}$ and $u_{x, y}$

Raster cells with values close to zero were located close to the sampling point while raster cells with values approaching one were located a considerable distance from the nearest sampling point. Uncertainty maps were produced for 1992, 2003, and for the change maps.

Cross-validations were performed to assess the quality of the interpolated maps by sequentially removing each sample and calculating a value for that site based on the remaining data. These predicted values were then compared to the measured values by calculating the correlation between predicted and measured soil properties, the mean and root mean squared errors of the predictions, and the $G$ value of the interpolated map (Schloeder, Zimmermann, \& Jacobs, 2001). The $G$ value represents how much better or worse an interpolated map captures the spatial variability of a property in comparison with interpolating the mean value of that property across the entire study area. Positive $G$ values indicate that interpolated maps are an improvement upon the sample mean map, whereas negative $G$ values indicate that the sample mean maps have better correspondence to the measured soil property values than the interpolated maps.

\section{Results and Discussion}

3.1 Descriptive statistics for the $0-10$ and $10-20 \mathrm{~cm}$ layers

The mean BD values in the $0-10 \mathrm{~cm}$ layer for $3 \mathrm{AN}$ in 1992 and 2003 were approximately double those of 
$3 \mathrm{AS}$ and of 3B (Table I). Mean BD values in the 10 $20 \mathrm{~cm}$ layer of 3AN in 1992 and 2003 were greater than double those of $3 \mathrm{AS}$ and 3B (Table I). Elevated $\mathrm{BD}$ values within selected areas of WCA-3 have been attributed to oxidation of organic matter and disturbances such as fire (Reddy et al., 1998). These results may also be related to the overdrained hydrologic conditions that have been reported in $3 \mathrm{AN}$ versus $3 \mathrm{AS}$ and $3 \mathrm{~B}$ in previous studies (David, 1996; Childers et al., 2003) that have lead to oxidation of low BD surface peat soils.

The mean TPm values reported in this study for 3AN and 3AS in 1992 were nearly identical and were approximately $75 \mathrm{mg} \mathrm{kg}^{-1}$ higher than that of $3 \mathrm{~B}$ (Table I). From 1992 to 2003, the mean TPm in 3AN increased by about $60 \mathrm{mg} \mathrm{kg}^{-1}$, the mean TPm in $3 \mathrm{AS}$ remained fairly constant, and the mean TPm in 3B increased by $15 \mathrm{mg} \mathrm{kg}^{-1}$ (Table I). Another study of southern 3AS reported a considerably higher mean $\mathrm{TPm}$ value of $592 \mathrm{mg} \mathrm{kg}^{-1}$ (Arfstrom, MacFarlane, \& Jones, 2000). However, a more recent study of $3 \mathrm{AS}$ reported a mean TPm of $362 \mathrm{mg} \mathrm{kg}^{-1}$ (Childers et al., 2003), which was more comparable to the mean reported for 3AS in this study. In 1992 mean TPm values in the $10-20 \mathrm{~cm}$ layer were highest in $3 \mathrm{AS}$ and nearly identical in 3AN and 3B (Table I). Mean TPm values in the $10-20 \mathrm{~cm}$ layer were highest in $3 \mathrm{AS}$ and nearly identical in $3 \mathrm{AN}$ and $3 \mathrm{~B}$ (Table I).

The mean $\mathrm{TPv}$ in the $0-10 \mathrm{~cm}$ layer of $3 \mathrm{AN}$ was double that of $3 \mathrm{AS}$ and nearly double that of $3 \mathrm{~B}$ (Table I). While the mean TPv decreased slightly in all areas from 1992 to 2003, the mean TPv for 3AN remained more than double that of $3 \mathrm{AS}$ and $3 \mathrm{~B}$. Despite recent reductions in $\mathrm{P}$ concentrations in surface water inflows to WCA-3 (South Florida Water Management District and Florida Department of Environmental Protection, 2004), it will probably take considerably longer for such improved water quality to be noticeable in the soil profile. Mean TPv values for the 10-20 cm layer in 1992 were highest in $3 \mathrm{AN}$ and nearly identical in $3 \mathrm{AS}$ and $3 \mathrm{~B}$ (Table I). In 2003, mean TPv values for $3 \mathrm{AN}$ were double those of 3AS and nearly double those of 3B (Table I).

Due to the high variability associated with each of the mean values, we cannot conclude that statistically significant increases have occurred in the mean values for $\mathrm{BD}, \mathrm{TPm}$, or $\mathrm{TPV}$ in $3 \mathrm{AN}, 3 \mathrm{AS}$, and $3 \mathrm{~B}$ from 1992 to 2003. However, we can report that there are trends in the data that provide useful information about soil dynamics in WCA-3. For example, in both layers from 1992 and 2003, mean BD in 3AN was generally more than double that of $3 \mathrm{AS}$ and $3 \mathrm{~B}$
Table I Summary statistics (mean $\pm 1 \mathrm{SD}$ ) for bulk density (BD), total phosphorus on a mass basis (TPm), and total phosphorus on a volumetric basis (TPv) from the $0-10 \mathrm{~cm}$ and 10-20 cm layers of WCA 3A North (3AN), 3A South (3AS), and 3B in 1992 and 2003

\begin{tabular}{|c|c|c|c|c|}
\hline Parameter, Area & $n$ & Units & $0-10 \mathrm{~cm} 1992$ & $0-10 \mathrm{~cm} 2003$ \\
\hline $\mathrm{BD}, 3 \mathrm{AN}$ & 72 & $\mathrm{~g} \mathrm{~cm}^{-3}$ & $0.20 \pm 0.13$ & $0.17 \pm 0.13$ \\
\hline $\mathrm{BD}, 3 \mathrm{AS}$ & 76 & $\mathrm{~g} \mathrm{~cm}^{-3}$ & $0.10 \pm 0.06$ & $0.07 \pm 0.05$ \\
\hline $\mathrm{BD}, 3 \mathrm{~B}$ & 28 & $\mathrm{~g} \mathrm{~cm}^{-3}$ & $0.12 \pm 0.04$ & $0.07 \pm 0.05$ \\
\hline TPm, 3AN & 72 & $\mathrm{mg} \mathrm{kg}^{-1}$ & $461 \pm 194$ & $523 \pm 292$ \\
\hline TPm, 3AS & 76 & $\mathrm{mg} \mathrm{kg}^{-1}$ & $458 \pm 173$ & $456 \pm 159$ \\
\hline TPm, 3B & 28 & $\mathrm{mg} \mathrm{kg}^{-1}$ & $385 \pm 184$ & $403 \pm 196$ \\
\hline $\mathrm{TPv}, 3 \mathrm{AN}$ & 72 & $\mu \mathrm{g} \mathrm{cm}{ }^{-3}$ & $84.5 \pm 45.7$ & $71.1 \pm 30.5$ \\
\hline TPv, 3AS & 76 & $\mu \mathrm{g} \mathrm{cm}^{-3}$ & $41.0 \pm 14.9$ & $27.6 \pm 17.6$ \\
\hline $\mathrm{TPv}, 3 \mathrm{~B}$ & 28 & $\mu \mathrm{g} \mathrm{cm}^{-3}$ & $45.1 \pm 18.1$ & $26.2 \pm 18.8$ \\
\hline Parameter, Area & $n$ & Units & 10-20 cm 1992 & $10-20 \mathrm{~cm} 2003$ \\
\hline $\mathrm{BD}, 3 \mathrm{AN}$ & 71 & $\mathrm{~g} \mathrm{~cm}^{-3}$ & $0.27 \pm 0.20$ & $0.30 \pm 0.25$ \\
\hline $\mathrm{BD}, 3 \mathrm{AS}$ & 75 & $\mathrm{~g} \mathrm{~cm}^{-3}$ & $0.13 \pm 0.13$ & $0.12 \pm 0.15$ \\
\hline $\mathrm{BD}, 3 \mathrm{~B}$ & 28 & $\mathrm{~g} \mathrm{~cm}^{-3}$ & $0.13 \pm 0.05$ & $0.14 \pm 0.07$ \\
\hline TPm, 3AN & 71 & $\mathrm{mg} \mathrm{kg}^{-1}$ & $252 \pm 104$ & $270 \pm 147$ \\
\hline TPm, 3AS & 75 & $\mathrm{mg} \mathrm{kg}^{-1}$ & $298 \pm 106$ & $328 \pm 147$ \\
\hline TPm, 3B & 28 & $\mathrm{mg} \mathrm{kg}^{-1}$ & $249 \pm 96$ & $307 \pm 172$ \\
\hline $\mathrm{TPv}, 3 \mathrm{AN}$ & 71 & $\mu \mathrm{g} \mathrm{cm}-3$ & $57.8 \pm 48.6$ & $64.8 \pm 50.7$ \\
\hline $\mathrm{TPv}, 3 \mathrm{AS}$ & 75 & $\mu \mathrm{g} \mathrm{cm}^{-3}$ & $34.6 \pm 16.8$ & $32.2 \pm 14.6$ \\
\hline $\mathrm{TPv}, 3 \mathrm{~B}$ & 28 & $\mu \mathrm{g} \mathrm{cm}^{-3}$ & $30.9 \pm 11.5$ & $35.2 \pm 14.0$ \\
\hline
\end{tabular}


suggesting that hydrologic alteration and fire have altered the soils of 3AN relative to the rest of WCA-3. An increasing trend in mean TPm values in both the 0-10 and 10-20 cm layers from 1992 to 2003 suggested that WCA-3 was susceptible to P enrichment. For $\mathrm{TPv}$, on the other hand, mean values in 3AN in 1992 and 2003 were consistently double those of $3 \mathrm{AS}$ and $3 \mathrm{~B}$ for both layers. This suggested that peat oxidation and fire have altered $\mathrm{P}$ storage dynamics across WCA-3 causing BD to be higher in $3 \mathrm{AN}$ than $3 \mathrm{AS}$ and $3 \mathrm{~B}$. The higher $\mathrm{TPm}$ and $\mathrm{TPv}$ values in $3 \mathrm{AN}$ may also be explained by surface water flow patterns as water generally moves southward from $3 \mathrm{AN}$ to $3 \mathrm{AS}$. To date, plant uptake, microbial immobilization, and storage of $\mathrm{P}$ in surface soils of $3 \mathrm{AN}$ may have prevented surface water TP from reaching $3 \mathrm{AS}$ and $3 \mathrm{~B}$.

3.2 Interpolated maps of bulk density and soil phosphorus in the $0-10 \mathrm{~cm}$ layer

Mapping the changes in the regional distribution of $\mathrm{BD}$ and TP across the $0-10 \mathrm{~cm}$ layer of WCA-3 is important because this layer, assuming an average peat accumulation rate for WCA-3 of $2.5 \mathrm{~mm}_{\text {year }}{ }^{-1}$ (Craft \& Richardson, 1993b), represents the accumulation of sediment and nutrients from about the last 40 years. Using this accumulation rate, about $2.75 \mathrm{~cm}$ of peat should have accumulated in WCA-3 from 1992 to 2003 . As maps for the $0-10$ and $10-20 \mathrm{~cm}$ layers showed generally the same spatial patterns, we present only those maps produced from the $0-10 \mathrm{~cm}$ layer.

The interpolated map for BD in 1992 from the 0$10 \mathrm{~cm}$ layer indicated that BD values were higher and more variable in $3 \mathrm{AN}$ than in $3 \mathrm{AS}$ or $3 \mathrm{~B}$ (Figure $3 \mathrm{a}$ ). This may be explained by inputs of sediment to $3 \mathrm{AN}$ from the Miami Canal and S11 WCS. Canal water has been shown to contain high suspended solid loads (particulates, clay, marl, etc.) that have been delivered to the WCAs over the past decades thus increasing the mineral content and BD of the peat soils (DeBusk et al., 1994). The interpolated map indicated that three compaction hot spots (BD values from 0.30 to $0.70 \mathrm{~g} \mathrm{~cm}^{-3}$ ) were present in $3 \mathrm{AN}$ in 1992. The northwestern and southwestern corners of $3 \mathrm{AS}$ also had higher BD values than the rest of $3 \mathrm{AS}$.

The interpolated map for BD from the $0-10 \mathrm{~cm}$ of WCA-3 in 2003 was comparable to that of 1992 , especially in the interior regions of $3 \mathrm{AS}$ and $3 \mathrm{~B}$. However, in both $3 \mathrm{AN}$ and $3 \mathrm{AS}$, the BD hotspots from 1992 had disappeared by 2003 . The highest BD values in 2003 were located in western $3 \mathrm{AN}$ and a new hotspot had formed (Figure $3 b$ ). The differences in the spatial distribution of BD from 1992 to 2003 may be a result of a fire in 1999 that burned much of 3AN (Stober et al., 2001). In the Everglades, peat fires have been shown to cause the physical reduction of surface soil and decreases in ground elevation which result in a new surface soil with a significantly higher BD (Smith et al., 2001). Alternatively, the differences may also be related to the different sampling techniques or the different sampling designs used in each of the sampling events.

The change map (Figure 3c) indicated that the greatest changes in BD from 1992 to 2003 were found in $3 \mathrm{AN}$. In sections of $3 \mathrm{AN}$ adjacent to the Miami Canal BD not only increased by $>0.5 \mathrm{~g} \mathrm{~cm}^{-3}$ (orange and red colors in Figure 3c), it also decreased by that amount (blue colors in Figure 3c). Generally, areas adjacent to canals or to the boundaries of $3 \mathrm{AN}$ and $3 \mathrm{AS}$ exhibited the greatest changes in $\mathrm{BD}$, while there was little change in the interior of $3 \mathrm{AS}$ and $3 \mathrm{~B}$. Interestingly, the western section of WCA-3 bordering Interstate 75 showed strong discontinuities in $\mathrm{BD}$ with values increasing to the north of the interstate and decreasing to the south of the interstate. The area to the south of I-75 that exhibited decreases in BD may be an artifact of the two different sampling designs. The 1992 sampling event included a site with high BD $\left(0.46 \mathrm{~g} \mathrm{~cm}^{-3}\right)$ close to I-75, while the nearest point from the 2003 sampling event was $2.3 \mathrm{~km}$ to the south and had a much lower BD value $\left(0.08 \mathrm{~g} \mathrm{~cm}^{-3}\right)$. This suggested that the uncertainty in our interpolated maps was highest in the northwestern part of 3AS. Overall, approximately $18 \%(42,640 \mathrm{ha})$ of the area of WCA-3 exhibited increases in BD from 1992 to 2003. Percent increases, however, were not consistent across each of the three hydrologic units. For example, BD increased in $29 \%(20,998$ ha) of $3 \mathrm{AN}, 16 \%$ (20,894 ha) of $3 \mathrm{AS}$, and only $2 \%$ (747 ha) of 3B.

The interpolated map for TPm in 1992 (Figure 4a) revealed generally low and homogeneous TPm concentrations across WCA-3. However, areas of $3 \mathrm{AN}$ and $3 \mathrm{AS}$ that received surface water inputs from the S339, S11, and S140 WCSs had much higher TPm concentrations. The highest TPm concentrations were observed in the northwestern section of $3 \mathrm{AS}$ in an 
a. 1992

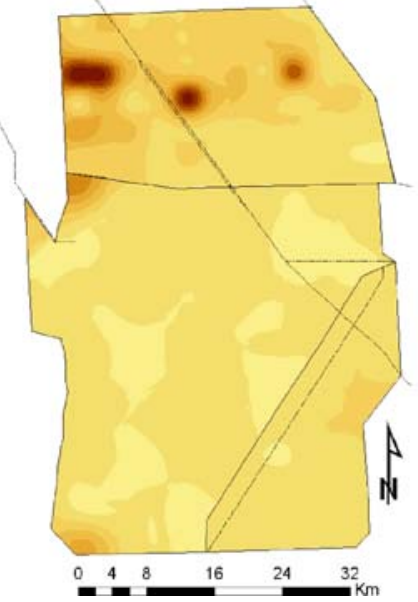

b. 2003

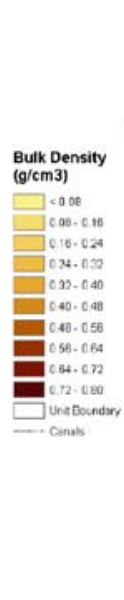

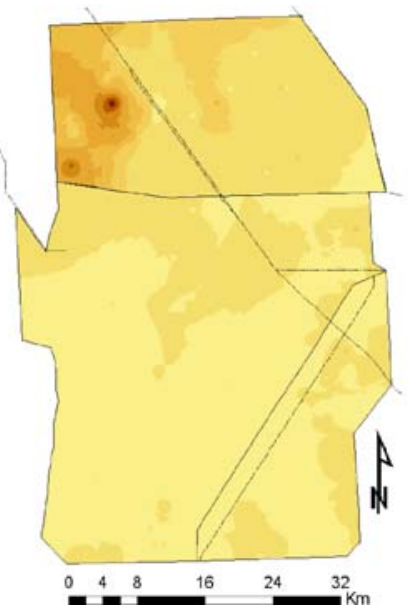

c. Change

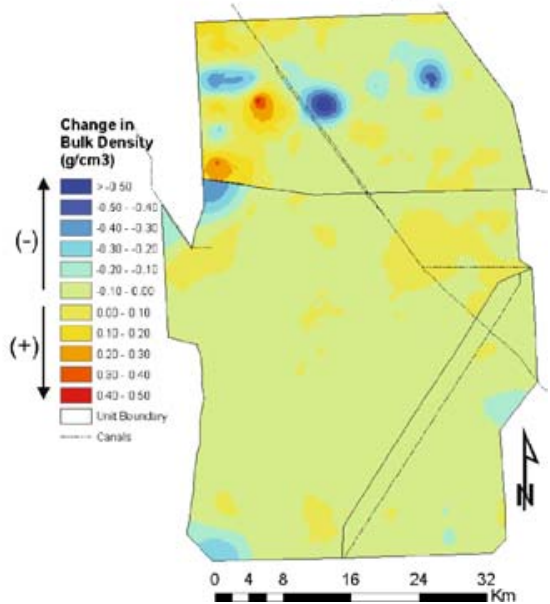

Figure 3 Interpolated maps showing the spatial distribution of (a) bulk density in the 0-10 cm layer from 1992, (b) bulk density in the 0-10 cm layer from 2003, and (c) the change in bulk density in the 0-10 cm layer from 1992 to 2003.

area near the S140 WCS where inputs from the L-28 canal flow into $3 \mathrm{AS}$. In this area, TP values ranged from 800 to $1,600 \mathrm{mg} \mathrm{kg}^{-1}$. This was considerably higher than the values in the $300-600 \mathrm{mg} \mathrm{kg}^{-1}$ range that generally occurred in the remainder of $3 \mathrm{AS}$. Hydrologic modifications to the Everglades landscape have created focal points in the landscape that receive nutrient inputs (Sklar et al., 2001). Another such focal point was observed in $3 \mathrm{AN}$ where the S339 WCS delivers water from the Miami Canal into the interior of 3AN. Plant cover data from WCA-3 showed that Typha had become dominant in these areas by the early 1990s (Davis \& Ogden, 1994). While the 1992 map indicated that TPm values in certain areas were elevated (500-1,600 $\mathrm{mg} \mathrm{kg}^{-1}$ range), these values were still not as high as those observed in enriched areas of WCA-2A (1,900-3,750 $\mathrm{mg} \mathrm{kg}^{-1}$ ) (Grimshaw, Rosen, Swift, Rodberg, \& Noel, 1993; McCormick \& O’Dell, 1996; Grunwald, Reddy, Newman, \& DeBusk, 2004).

In general, the interpolated map for TPm in 2003 (Figure 4b) showed a similar spatial pattern than that of TPm in 1992. Total Pm was highest in the peripheral areas of WCA-3 that received surface water inputs from canals. As in 1992, high TPm concentrations in 2003 were observed in the northwestern section of $3 \mathrm{AS}$ in the area that has received inputs from the L-28 canal and in the southeastern section of $3 \mathrm{AN}$ that has received inputs from the $\mathrm{S} 11$
WCSs. The 2003 map also indicated the TPm hotspot that was noticeable in central 3AN in 1992, had expanded considerably by 2003 . Not only had this area expanded, but it also shifted to the northwest and contained TPm concentrations in the 1,200-2,000 mg $\mathrm{kg}^{-1}$ range. This increase in concentration of TPm is most likely related to surface water inputs from the Miami Canal that were diverted into WCA-3 by the S339 WCS. For example, recent water quality data for WCA-3 indicated that the geometric mean concentration of TP in surface water inflows to WCA-3A $\left(26.3 \mu \mathrm{g} \mathrm{L}^{-1}\right)$ was found to be three times higher than the geometric mean for TP in the interior regions of WCA-3A $\left(7.6 \mu \mathrm{g} \mathrm{L}^{-1}\right)$ (South Florida Water Management District and Florida Department of Environmental Protection, 2004).

As shown with the TPm change map (Figure 4c), changes in TPm ranged between $\pm 250 \mathrm{mg} \mathrm{kg}^{-1}$ for approximately $91 \%$ of WCA-3. There were various localized areas in which TPm increased or decreased to a greater extent. For example, the area with the greatest increases in TPm was the hotspot that had developed in the 2003 map. In this area, adjacent to the Miami Canal and near the S339 WCS, TPm showed increases from 500 to $1,500 \mathrm{mg} \mathrm{kg}^{-1}$ over the 11 year period. Large decreases in TPm also occurred in areas to the east of the S339 hotspot and also in the southwestern part of 3B. Interestingly, there appeared to be a slight decrease in TPm along a northeast to 
a. 1992

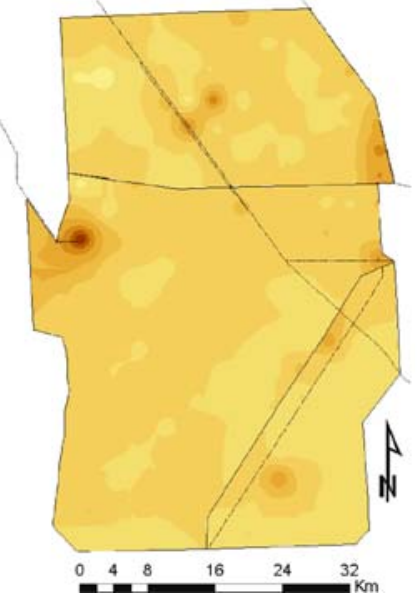

b. 2003

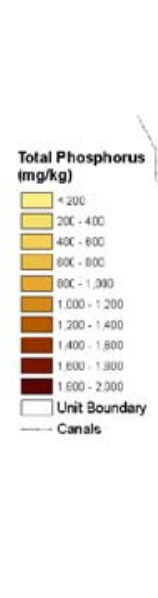

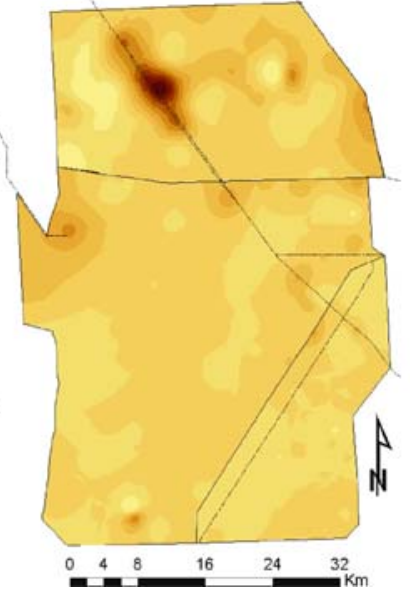

c. Change

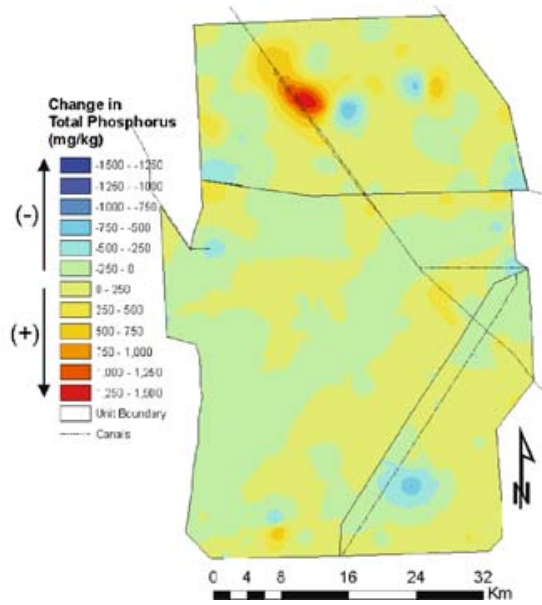

Figure 4 Interpolated maps showing the spatial distribution of (a) total phosphorus $\left(\mathrm{mg} \mathrm{kg}^{-1}\right)$ in the $0-10 \mathrm{~cm}$ layer from 1992 ,

(b) total phosphorus $\left(\mathrm{mg} \mathrm{kg}^{-1}\right)$ in the $0-10 \mathrm{~cm}$ layer from 2003,

and (c) the change in total phosphorus $\left(\mathrm{mg} \mathrm{kg}^{-1}\right)$ in the $0-10 \mathrm{~cm}$ layer from 1992 to 2003.

southwest axis in $3 \mathrm{AS}$ that corresponds to the flow path of surface water through this region. The reduction in soil TPm along this flow path may be related to the decreased concentrations of surface water TP that are entering and passing through $3 \mathrm{AS}$.

Total Pm increased in approximately 53\% (127,165 ha) of the area of WCA-3 from 1992 to 2003. As with BD, increases in TPm, however, were not consistent across each of the three hydrologic units. For example, TPm increased in $65 \%$ (47,510 ha) of the area of $3 \mathrm{AN}, 44 \%$ $(55,991 \mathrm{ha})$ of $3 \mathrm{AS}$, and $60 \%$ (23,664 ha) of 3B. Historical background TPm concentrations in WCA-2A have been estimated to be less than $500 \mathrm{mg} \mathrm{kg}^{-1}$ (DeBusk, Newman, \& Reddy, 2001). Adopting this estimate for WCA-3, according to our interpolated maps for 1992, 23\% $(16,576 \mathrm{ha})$ of $3 \mathrm{AN}, 21 \%(26,768 \mathrm{ha})$ of $3 \mathrm{AS}$, and a. 1992

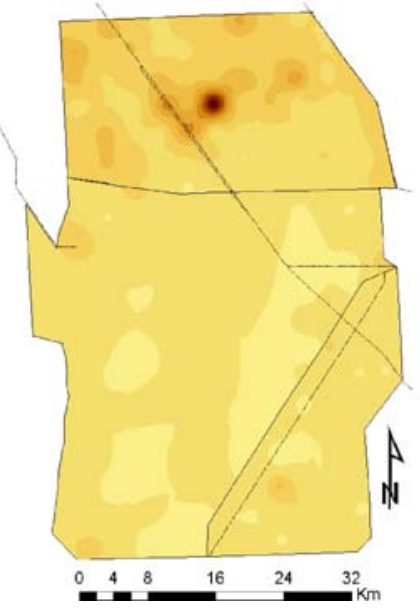

b. 2003

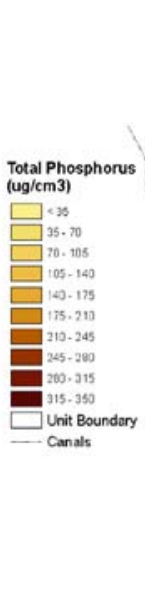

\section{(b. 2003}

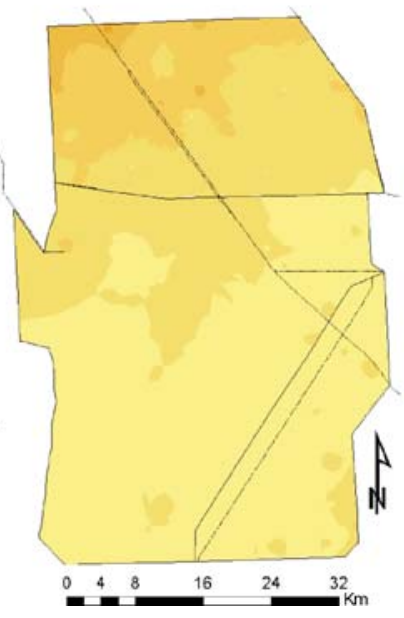

c. Change

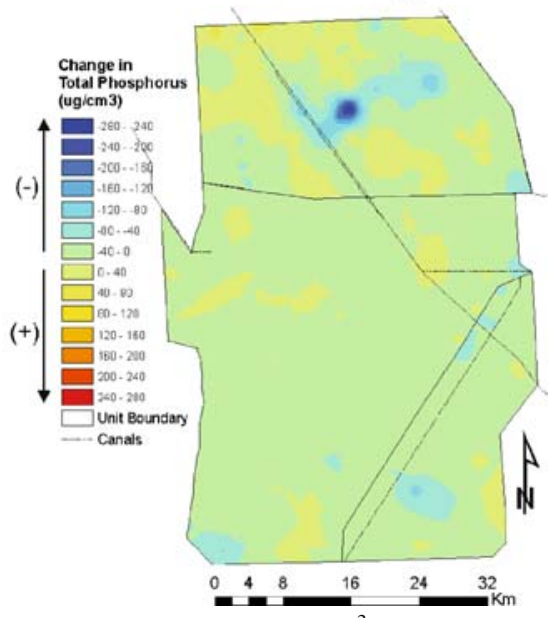

Figure 5 Interpolated maps showing the spatial distribution of and (c) the change in total phosphorus $\left(\mu \mathrm{g} \mathrm{cm}{ }^{-3}\right)$ in the $0-10 \mathrm{~cm}^{-3}$ (a) total phosphorus $\left(\mu \mathrm{g} \mathrm{cm}^{-3}\right)$ in the $0-10 \mathrm{~cm}$ layer from 1992 ,

(b) total phosphorus $\left(\mu \mathrm{g} \mathrm{cm}^{-3}\right)$ in the $0-10 \mathrm{~cm}$ layer from 2003 , 
$16 \%(6,256 \mathrm{ha})$ of $3 \mathrm{~B}$ showed elevated TPm levels in 1992. By 2003, the percent area of WCA-3 with elevated TPm levels had increased considerably in $3 \mathrm{AN}$ to $53 \%$ $(38,479 \mathrm{ha})$, increased slightly in $3 \mathrm{AS}$ to $23 \%$ (29,356 ha), and actually decreased slightly in $3 \mathrm{~B}$ to $10 \%$ (4,100 ha). By comparison, DeBusk et al. (2001) calculated that for soil cores collected in 1998, 73\% (31,777 ha) of WCA-2A had elevated soil TP levels. In WCA-3 from 1992 to 2003, we estimated that the area with $\mathrm{TPm}>500 \mathrm{mg} \mathrm{kg}^{-1}$ increased at a rate of approximately $1 \%$ year $^{-1}$. While this represented a considerably high rate of increase, it was still lower than a rate of $5.25 \%$ year $^{-1}$ calculated for WCA-2A from 1991 to 1998 (DeBusk et al., 2001). Our data indicated that while nutrient loading to WCA-3 has affected a smaller percentage of the area of WCA-3 than WCA-2A, the total area of WCA-3 with TPm $>500 \mathrm{mg} \mathrm{kg}^{-1}$ in both 1992 and 2003 was greater than the total area of WCA-2A with TPm $>500 \mathrm{mg} \mathrm{kg}^{-1}$ in 1998 . Slowing the increase of soil TPm in WCA-3 is even more critical in light of recent research that has shown that soils respond more slowly to elevated TP than other ecosystem components such as periphyton, floc, and plants (Newman et al., 2004; Gaiser et al., 2005).

The interpolated map for TPv in 1992 (Figure 5a) showed a fairly low and homogeneous distribution of TPv across 3AS and 3B. In contrast, the northern and peripheral areas of WCA-3 had much higher and more variable $\mathrm{TPv}$ concentrations. The highest $\mathrm{TPv}$ concentrations were observed in the central section of $3 \mathrm{AN}$ in an area that received inputs from the Miami Canal via the S339 WCS. In this area TPv ranged from 100 to $350 \mu \mathrm{g} \mathrm{cm}^{-3}$. This was considerably higher than the values in the $35-100 \mu \mathrm{g} \mathrm{cm}^{-3}$ range that generally occurred in the rest of 3AN in 1992.

In 2003, TPv remained low and homogeneous across $3 \mathrm{AS}$ and $3 \mathrm{~B}$, while the northwestern and peripheral areas of $3 \mathrm{AN}$ had much higher TPv. The shift in distribution of TPv from 1992 to 2003 may be explained by the large fire in 1999 that burned much of this area (Stober et al., 2001). More research is needed to assess the short and long-term effects of fire on soil BD and TP in WCA-3, and how fire interacts with hydrology and vegetation to influence soil properties.

The $\mathrm{TPv}$ change map (Figure $5 \mathrm{c}$ ) indicated that TPv increased in only 16\% of WCA-3 from 1992 to 2003. While there were a few areas in $3 \mathrm{AN}$ that had small increases in $\mathrm{TPv}$, most other areas of $3 \mathrm{AN}$,
3AS, and $3 \mathrm{~B}$ exhibited decreases in $\mathrm{TPv}$ ranging from -40 to $-280 \mu \mathrm{g} \mathrm{cm}^{-3}$. As with $\mathrm{BD}$ and $\mathrm{TPm}$, increases in TPv were not consistent across each of the hydrologic zones. For example, TPv increased in $35 \%(25,740 \mathrm{ha})$ of the area of $3 \mathrm{AN}, 8 \%(9,940 \mathrm{ha})$ of the area of $3 \mathrm{AS}$, and $6 \%(2,354 \mathrm{ha})$ of the area in $3 \mathrm{~B}$. If we assume the average pre-impact $\mathrm{BD}$ value for WCA-3 to be $0.10 \mathrm{~g} \mathrm{~cm}^{-3}$ (McCormick et al., 2001), multiplying this value by the average preimpact TPm of $500 \mathrm{mg} \mathrm{P} \mathrm{kg}^{-1}$ (DeBusk et al., 2001), then the historic $\mathrm{TPv}$ values prior to nutrient and impacts should be less than $50 \mu \mathrm{g} \mathrm{cm}^{-3}$. Adopting this value for WCA-3, according to our interpolated maps for 1992, 93\% (67,269 ha) of 3AN had elevated TPv. By comparison, only 20\% (24,932 ha) of $3 \mathrm{AS}$ and 28\% (19,066 ha) of 3B showed elevated TPv. By 2003, there was a reduction in area with $\mathrm{TPv}>50 \mu \mathrm{g}$ $\mathrm{cm}^{-3}$, as only $92 \%(66,555 \mathrm{ha})$ of $3 \mathrm{AN}, 7.4 \%$ (9,468 ha) of $3 \mathrm{AS}$, and $1.4 \%$ (537 ha) of $3 \mathrm{~B}$ showed elevated TPv levels. Overall, the area of WCA-3 with $\mathrm{TPv}>50 \mu \mathrm{g} \mathrm{cm}^{-3}$ decreased from $42 \%$ in 1992 to $32 \%$ in 2003.

We also created maps based on the distance from sampling points to provide information about the uncertainty of our interpolated maps (Figure 6). Lower standardized uncertainty values $(0-0.3)$ corresponded to areas that were close to sampling points, while higher values $(0.7-1)$ corresponded to areas that were far away from sampling points. As splines are exact interpolators, our predictions of $\mathrm{BD}$ or $\mathrm{TP}$ values at the actual sampling points were identical to the measured values. Moving away from the sample points, however, the uncertainty of the predicted values increased with distance. For 1992, the sampling event with the irregular grid design, most of the uncertainty map had low standardized values (Figure 6a). This was especially true for $3 \mathrm{AN}$ where there were only a few locations where standardized uncertainty was greater than 0.3 . For $3 \mathrm{AS}$ and $3 \mathrm{~B}$, standardized uncertainty increased where the spacing between grid nodes became coarser. Standardized uncertainties were greatest in the far western part of 3AS near the L-28 gap, as no samples were collected from this area. There was also a part of southwestern $3 \mathrm{~B}$ adjacent to the L-67 canal with higher uncertainty values, as our sample coverage in that area was sparse. For 2003 (Figure 6b), the patterns in uncertainty were different as a result of the stratified random design. Again, uncertainties were smallest in 
a. 1992

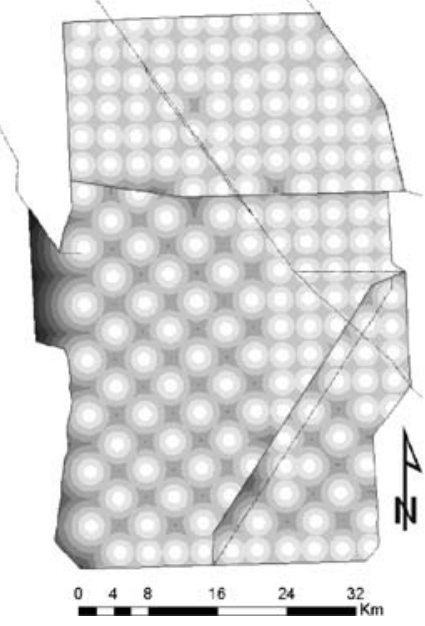

b. 2003

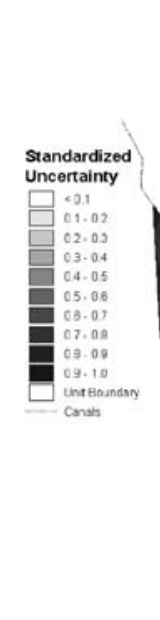

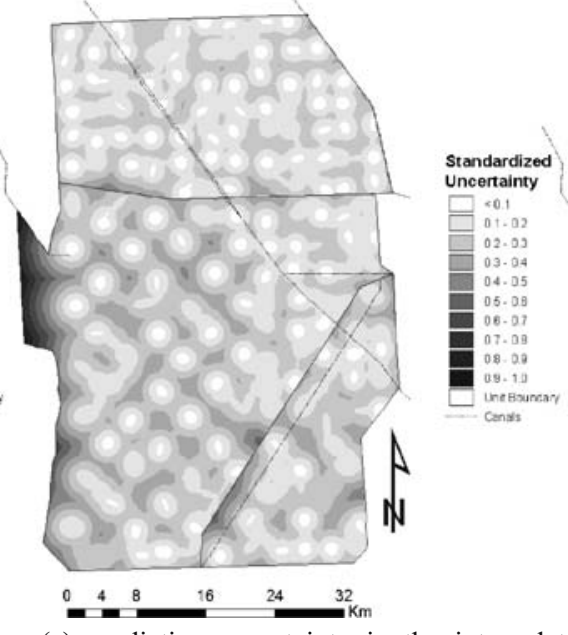

c. Change

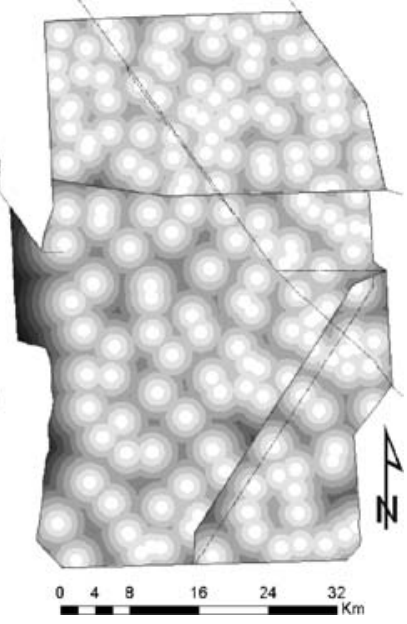

Figure 6 Standardized uncertainty maps showing (a) prediction uncertainty in the interpolated maps for 1992, (b) prediction uncertainty in the interpolated maps for 2003 , (c) the combined prediction uncertainty in the interpolated change maps.

$3 \mathrm{AN}$, and increased in $3 \mathrm{AS}$ and $3 \mathrm{~B}$. The highest uncertainties were observed along the western boundary of $3 \mathrm{AS}$ and in the L-28 gap. There were also parts of $3 \mathrm{~B}$, especially around the boundaries of the area, for which uncertainties were high. For the change map, we had comprehensive coverage of $3 \mathrm{AN}$, generally good coverage of $3 \mathrm{~B}$, and fair coverage of 3AS. Again the western sections of $3 \mathrm{AS}$ and the western part of $3 \mathrm{~B}$ near the L-67 canals had the highest distances and associated uncertainty. This GIS-based map algebra technique could be utilized in future studies to quantify uncertainty and identify areas that require additional sampling.

Cross-validation for the $0-10 \mathrm{~cm}$ layer in 1992 revealed that correlations between predicted and measured values ranged from -0.50 for $\mathrm{TPv}$ in $3 \mathrm{~B}$ to a high of 0.46 for $\mathrm{TPv}$ in $3 \mathrm{AS}$ (Table II). Correlations were generally higher for $3 \mathrm{AN}$ and 3AS than for 3B. Mean errors were negative for most soil properties in the three zones, indicating that on average, we slightly underpredicted BD, TPm, and TPv. $G$ values for five of the nine properties mapped in 1992 were positive, indicating that these interpolated maps represented a significant improvement from the interpolation of the sample mean across the different zones of WCA-3 (Schloeder et al., 2001). The highest $G$ values were calculated for $\mathrm{TPv}$ in $3 \mathrm{AS}$ and $\mathrm{BD}$ in $3 \mathrm{AN}$, indicating that these were the best two interpolated maps for the 1992 sampling.
Cross-validation for the $0-10 \mathrm{~cm}$ layer in 2003 , by comparison, revealed that correlations between predicted and measured values ranged from -0.34 for $\mathrm{TPm}$ in $3 \mathrm{~B}$ to a high of 0.56 for TPm in $3 \mathrm{AN}$ (Table II). Correlations for $3 \mathrm{AN}$ were $>0.40$, for $3 \mathrm{AS}$ were $>0.08$, and for $3 \mathrm{~B}$ were $<0$. Similar to 1992 , mean errors in the 2003 data were negative for most soil properties in the three zones, indicating we slightly underpredicted BD, TPm, and TPv. $G$ values for four of the nine properties mapped in 1992 were positive, indicating that these were a significant improvement from the interpolation of the sample mean across WCA-3 (Schloeder et al., 2001). The highest $\mathrm{G}$ values were calculated for BD and TPm in 3AN. Overall, the maps for the 1992 sampling exhibited lower cross-validation prediction errors than the maps from 2003. This may be related to the reconstruction technique used to match the 2003 data to the 1992 data or to the differences in the sampling designs from 1992 and 2003. In addition, maps of $3 \mathrm{AN}$ and $3 \mathrm{AS}$ had less error than maps of $3 \mathrm{~B}$, indicating that future samplings of $3 \mathrm{~B}$ should attempt to collect greater numbers of samples from this zone of WCA-3. As the change map was a combination of the 1992 and 2003 maps, it should be noted that it integrated the errors from both sampling events and thus was associated with considerable uncertainty.

Despite the uncertainty surrounding the estimation of recent changes in TPm and TPv in WCA-3, it is clear 
Table II Interpolation parameters and cross-validation statistics for bulk density (BD) and total phosphorus on a mass (TPm) and volumetric basis (TPv) from the $0-10 \mathrm{~cm}$ layer in 1992 and 2003 $\uparrow$ Pearson correlation between measured TP values and those predicted by interpolation.

\$ Goodness of prediction $(G)$, as defined by Schloeder et al. (2001).

\begin{tabular}{llllll}
\hline Hydrologic unit, year & Parameter & Correlation $\dagger$ & Mean Error & $\begin{array}{l}\text { Root Mean } \\
\text { Square Error }\end{array}$ & G+ \\
& & & & 0.11 & 16.3 \\
\hline 3AN, 1992 & BD & 0.45 & 0.002 & 0.05 & 0.7 \\
3AS, 1992 & BD & 0.27 & -0.002 & 0.03 & 8.3 \\
3B, 1992 & BD & 0.36 & 0.001 & 191.9 & 0.4 \\
3AN, 1992 & TPm & 0.25 & -5.8 & 208.6 & -47.8 \\
3AS, 1992 & TPm & -0.21 & -1.5 & 194.0 & -14.9 \\
3B, 1992 & TPm & 0.05 & -2.3 & -1.9 \\
3AN, 1992 & TPv & 0.24 & -0.21 & 45.8 & 18.2 \\
3AS, 1992 & TPv & 0.46 & -0.69 & 13.3 & -57.7 \\
3B, 1992 & TPv & -0.50 & -0.27 & 22.3 & 25.0 \\
3AN, 2003 & BD & 0.51 & -0.001 & 0.11 & -20.6 \\
3AS, 2003 & BD & 0.08 & 0.002 & 0.05 & -42.3 \\
3B, 2003 & BD & -0.22 & 0.002 & 0.05 & 31.2 \\
3AN, 2003 & TPm & 0.56 & -16.0 & 240.1 & -18.4 \\
3AS, 2003 & TPm & 0.08 & -15.5 & 171.5 & -52.7 \\
3B, 2003 & TPm & -0.34 & 17.7 & 238.4 & 13.8 \\
3AN, 2003 & TPv & 0.41 & -0.94 & 28.11 & 11.0 \\
3AS, 2003 & TPv & 0.39 & -0.20 & 16.5 & -48.8 \\
3B, 2003 & TPv & -0.24 & -0.89 & 22.5 & \\
\hline & & & & &
\end{tabular}

that the majority of the changes have been occurring in the soils of $3 \mathrm{AN}$. This area experienced the most dynamic changes in $\mathrm{BD}, \mathrm{TPm}$, and TPv. In the interior regions of $3 \mathrm{AS}$ and $\mathrm{BB}$ on the other hand, $\mathrm{BD}, \mathrm{TPm}$, and $T P v$ did not exhibit much change. This suggests that CERP activities for WCA-3 should focus on reducing TP inputs to $3 \mathrm{AN}$ from the Miami Canal, the L-28 Canal, and the S11 WCS. Certain areas in close proximity to the canals (Figures 4 and 5) exhibited elevated soil TPm and TPv in considerable excess of background levels. The removal of the Miami Canal, a proposed CERP activity (U.S. Army Corps of Engineers, 2005), might also create an area of high TP loading where the remnant canal enters 3AN. Nevertheless, without reducing nutrient inputs into WCA-3, the ecological integrity of this ecosystem will be compromised possibly causing greater shifts from Cladium to Typha vegetative communities.

Using the map algebra tools in ArcGIS we also calculated the total amount of $P$ in the $0-10$ and 10 $20 \mathrm{~cm}$ layers for 1992 and 2003. Using this rasterbased approach we estimated that there was approximately $23,015 \mathrm{mt} \mathrm{P}$ in the upper $0-20 \mathrm{~cm}$ of floc and soil in WCA-3 in 1992. In 2003, by comparison, we estimated that there was $20,099 \mathrm{mt} \mathrm{P}$ in the upper $0-20 \mathrm{~cm}$ (Table III). The decrease in TP storage in WCA-3 during this period was most likely due to the decreases in surface water TP inputs to WCA-3 as a result of the establishment of best management practices (BMPs) in the EAA in combination with the creation of STAs to the north of WCA-3 (South Florida Water Management District and Florida Department of Environmental Protection, 2004). For example, in the early 1990s, annual P loading from all sources, including precipitation was estimated to be $269 \mathrm{mt}$ per year (South Florida Water Management District, 1992). More recent data indicated that $\mathrm{P}$ loading to the WCAs decreased to approximately $136 \mathrm{mt}$ in 2003 and $112 \mathrm{mt}$ in 2004 (South Florida Water Management District and Florida Department of Environmental Protection, 2004). This reduction in surface water TP inputs may lead to a reduction in $\mathrm{P}$ concentration and storage in the floc and surface soil horizons. However, recent fires that have burned large areas of WCA-3 (Stober et al. 2001) and processes such as resuspension of floc and translocation of soil TP in both horizontal and vertical directions may also explain some of the changes in soil TP storage. Further research is needed to determine the spacetime trajectories of $\mathrm{P}$ storage in the floc and surface soils of WCA-3, and what mechanism or mechanisms are driving these changes.

Breaking the data up by layer and by hydrologic unit revealed that TP storage in the upper $0-10 \mathrm{~cm}$ 
Table III Total phosphorus storage in the $0-10$ and 10-20 cm layers in 1992 and 2003

\begin{tabular}{lllll}
\hline Total P storage $(\mathrm{mt} \mathrm{P})$ & Year & $0-10 \mathrm{~cm}$ layer & $10-20 \mathrm{~cm}$ layer & Combined layers \\
\hline 3AN & 1992 & 6,053 & 4,292 & 10,345 \\
3AS & 1992 & 5,326 & 4,335 & 9,661 \\
3B & 1992 & 1,794 & 1,215 & 3,009 \\
Total & 1992 & 13,173 & 9,842 & 23,015 \\
3AN & 2003 & 5,089 & 4,901 & 9,990 \\
3AS & 2003 & 3,638 & 4,084 & 7,722 \\
3B & 2003 & 1,004 & 1,383 & 2,387 \\
Total & 2003 & 9,731 & 10,368 & 20,099 \\
\hline
\end{tabular}

layer decreased from 1992 to 2003 while TP storage in the lower 10-20 cm layer increased from 1992 to 2003 (Table III). This indicated that new peat being accreted in WCA-3 has lower TP concentrations than the peat that was accreted during the 1980s and 1990s. It is important to point out that this system is dynamic, complex, and that processes such as peat oxidation, fire, resuspension of floc, and redistribution of soil TP may act and interact to confound the 1992 to 2003 comparison by introducing spatial and temporal irregularities or causing inconsistencies across the mass and volumetric datasets. Across the hydrologic units, there were decreases in P storage in the upper $0-10 \mathrm{~cm}$ from 1992 to 2003 in $3 \mathrm{AN}, 3 \mathrm{AS}$, and $3 \mathrm{~B}$. In the 10-20 cm layer, however, TP storage actually increased in $3 \mathrm{AN}$ and $3 \mathrm{~B}$ suggesting changes in the $\mathrm{P}$ content of litter or translocation of $\mathrm{P}$ to deeper horizons. Total P storage in 3AS decreased from 1992 to 2003 , which may be related to the ponding of water behind the Tamiami Trail (David, 1996; Childers et al., 2003) that causes overflooding in 3AS resulting in the mobilization of $\mathrm{P}$ from subsurface anaerobic soil layers.

The changes documented in the spatial distributions and total storage of TP from 1992 to 2003 present an interesting challenge for management and restoration of WCA-3. For example, in some areas of WCA-3 (near the S339 WCS), TPm concentrations have increased considerably, suggesting that additional efforts may be needed to decrease surface water TP inputs to this area. However, BD and TPv values near the S339 structure have both decreased indicating that less $\mathrm{P}$ is being stored per unit volume of soil. In other areas (such as central $3 \mathrm{AS}$ and 3B), decreases in both TPm and TPv imply that both P concentration and storage are currently less than they were in the early 1990s. If the decreases in BD observed across most of
WCA-3 are not just an artifact of different sampling designs and protocols, this suggests that there has been a reduction in mineral inputs to WCA-3 and a concomitant reduction in the storage of mineral material (including P) in the surface soils.

The 1992 and 2003 maps will be useful to document future changes in soil $\mathrm{P}$ dynamics and to determine the space-time trajectories for $\mathrm{P}$ concentration and storage in this system. These maps also illustrated that considerably different patterns emerge depending on the choice of units for soil TP. Thus, there is value in presenting data in both mass and volumetric units in future studies and for considering both types of units for management and regulatory purposes.

\section{Summary and Conclusions}

Interpolated values for $\mathrm{BD}, \mathrm{TPm}$, and $\mathrm{TPv}$ were highest in $3 \mathrm{AN}$ and $3 \mathrm{AS}$, especially in areas that were adjacent to or received surface water inputs from canals. In 1992, approximately $21 \%$ of the upper 0-10 cm soil layer in WCA-3 had TPm concentrations that were greater than $500 \mathrm{mg} \mathrm{kg}^{-1}$, indicating elevated nutrient conditions. By comparison, in 2003, nearly $30 \%$ of WCA-3 showed elevated TP levels. This indicated that during this period, the area of WCA-3 with enriched TPm concentrations increased about one $\%$ year $^{-1}$. The most impacted zone of WCA-3 was 3AN which had hotspots of high BD, $\mathrm{TPm}$, and TPv that were the result of a combination of surface water $P$ inputs via canals and peat oxidation from fire and overdrainage. The least impacted areas of WCA-3 were the central 3AS and 3B that had quite low and homogenous TPm and TPv distributions. Despite hydrologic alterations and 
changes in nutrient loading to WCA-3, the soils in parts of $3 \mathrm{AS}$ and $3 \mathrm{~B}$ remain relatively unimpacted by $\mathrm{P}$.

Change maps revealed that distributions of $\mathrm{BD}$, $\mathrm{TPm}$, and $\mathrm{TPv}$ can vary in WCA-3 over relatively short time periods, especially in those areas that experience drainage or fire. This indicates that future spatially-explicit mapping of soil properties in WCA3 should be conducted in the next 5-10 years in order to maintain a detailed and current understanding of these properties. The distance from sampling points was used to assess the uncertainty in the 1992, 2003, and change maps. The highest standardized uncertainties were located in western $3 \mathrm{AS}$ and in the boundary areas of $3 \mathrm{~B}$. Uncertainty was lowest for $3 \mathrm{AN}$, the region that experienced the greatest changes in soil properties. Cross-validation indicated that maps from 1992 usually had lower prediction errors than maps from 2003, while maps from 3AN and $3 \mathrm{AS}$ generally had lower prediction error than $3 \mathrm{~B}$.

We estimated that approximately 23,015 $\mathrm{mt} \mathrm{P}$ was stored in the upper $0-20 \mathrm{~cm}$ of floc and soil in WCA3 in 1992 compared to 20,099 $\mathrm{mt} \mathrm{P}$ in 2003. The decrease in TP storage during this period was most likely due to the decreases in surface water TP inputs to WCA-3, recent fires, and processes such as resuspension of floc and translocation of soil TP. Breaking the data up by layer revealed that TP storage in the upper 0-10 $\mathrm{cm}$ layer decreased from 1992 to 2003 while TP storage in the lower 10-20 cm layer increased from 1992 to 2003 . This indicated that new peat being accreted in WCA-3 has lower TP concentrations than the peat that was accreted during the 1980s and 1990s.

The mapping of BD and TPv in addition to TPm, revealed new insights into the spatial and temporal dynamics of soil P in WCA-3 as maps displayed on a concentration basis showed different patterns than maps displayed on a volumetric basis. Mapping across spacetime trajectories facilitates the evaluation of transitions in edaphic properties in wetlands that cannot be achieved from site-specific or transect studies. The summary statistics, maps, and other calculations presented in this study will serve as reference information that will be critical in the evaluation of future management and restoration activities. More generally, the combination of the geostatistical and GIS techniques used in this study may provide a model for future research designed to quantify space-time trajectories of soil properties across various ecosystems.
Acknowledgments Funding was provided by the South Florida Water Management District. We would like to thank C. Fitz, N. Wang, and J. Godin of the SFMWD for assisting in the development of the stratified random sampling design used in the 2003 sampling, T. Jones of Aircoastal Helicopter for his support of the project, Y. Wang of the WBL for her work with the laboratory analyses, and R. Rivero for her assistance with the GIS analyses.

\section{References}

Anderson, J. M. (1976). An ignition method for determination of total phosphorus in lake sediments. Water Research, 10, 329-331.

Arfstrom, C., MacFarlane, A., \& Jones, R. D. (2000). Distribution of mercury and phosphorus in everglades soils from water conservation area 3A, Florida, U.S.A. Water, Air, and Soil Pollution, 121, 133-159.

Brown, R. B., Stone, E. L., \& Carlisle, V. W. (1991). Soils. In R. L. Myers \& J. J. Ewl (Eds.), Ecosystems of Florida. Orlando, FL: University of Central Florida Press.

Bruland, G. L., Grunwald, S., Osborne, T. Z., Reddy, K. R., \& Newman, S. (2006). Spatial Distribution of Soil Properties in Water Conservation Area 3 of the Everglades. Soil Science Society of American Journal, 70, 1662-1676.

Bruland, G. L., \& Richardson, C. J. (2004). A spatially explicit investigation of $\mathrm{P}$ sorption and related soil properties in two riparian wetlands. Journal of Environmental Quality, 33, 785-794.

Childers, D. L., Doren, R. F., Jones, R., Noe, G. B., Rugge, M., \& Scinto, L. J. (2003). Decadal changes in vegetation and soil phosphorus pattern across the Everglades landscape. Journal of Environmental Quality, 32, 344-362.

Craft, C. B., \& Richardson, C. J. (1993a). Peat accretion and phosphorus accumulation along a eutrophication gradient in the northern Everglades. Biogeochemistry, 22, 133-156.

Craft, C. B., \& Richardson, C. J. (1993b). Peat accretion and N, $\mathrm{P}$, and organic $\mathrm{C}$ accumulation in nutrient-enriched and unenriched Everglades peatlands. Ecological Applications, 3, 446-458.

Craft, C. B., \& Richardson, C. J. (1997). Relationships between soil nutrients and plant species composition in Everglades peatlands. Journal of Environmental Quality, 26, 224-232.

David, P. G. (1996). Changes in plant communities relative to hydrologic conditions in the Florida Everglades. Wetlands, $16,15-23$.

Davis, S. M. (1991). Growth, decomposition, and nutrient retention of Cladium jamaicense Crantz and Typha domigensis Pers. in the Florida Everglades. Aquatic Botany, 40, 203-224.

Davis, S. M. (1994). Phosphorus inputs and vegetation sensitivity in the Everglades. In S. M. Davis \& J. C. Ogden (Eds.), Everglades: The ecosystem and its restoration. Delray Beach, FL: St. Lucie.

Davis, S. M., \& Ogden, J. C. (Eds.) (1994). Everglades: The ecosystem and its restoration. Delray Beach, FL: St. Lucie.

DeBusk, W. F., Newman, S., \& Reddy, K. R. (1994). Spatial patterns of soil phosphorus in Everglades Water Conservation Area 2A. Soil Science Society of American Journal, $58,543-552$. 
DeBusk, W. F., Newman, S., \& Reddy, K. R. (2001). Spatiotemporal patterns of soil phosphorus enrichment in Everglades Water Conservation Area 2A. Journal of Environmental Quality, 30, 1438-1446.

Drake, H. L., Aumen, N. G., Kuhner, C., Wagner, C., Griebhammer, A., \& Schmittroth, M. (1996). Anaerobic microflora on Everglades sediments: Effects of nutrients on population profiles and activities. Applied and Environmental Microbiology, 62, 486-493.

Gaiser, E. E., Trexler, J. C., Richards, J. H., Childers, D. L., Lee, D., Edwards, A. L., et al. (2005). Cascading ecological effects of low-level phosphorus enrichment in the Florida Everglades. Journal of Environmental Quality, 34, 717-723.

Gleason, P. J., Cohen, A. D., Stone, P., Smith, W. G., Brooks, H. K., Goodrick, R., et al. (1974). The environmental significance of Holocene sediments from the Everglades and saline tidal plains. In P. J. Gleason (Ed.), Environments of south Florida, present, and past (pp 297-351). Coral Gables, FL: Miami Geol. Soc.

Grimshaw, H. J., Rosen, M., Swift, D. R., Rodberg, K., \& Noel, J. M. (1993). Marsh phosphorus concentrations, phosphorus content and species composition of Everglades periphyton communities. Archiv fur Hydrobiologie, 128, 257-276.

Grunwald, S., Reddy, K. R., Newman, S., \& DeBusk, W. B. (2004). Spatial variability, distribution, and uncertainty assessment of soil phosphorus in a south Florida wetland. Journal of Envirometrics, 15, 811-825.

King, R. S., Richardson, C. J., Urban, D. L., \& Romanowicz, E. A. (2004). Spatial dependency of vegetation-environment linkages in an anthropogenically influenced wetland ecosystem. Ecosystems, 7, 75-97.

Koch, M. S., \& Reddy, K. R. (1992). Distribution of soil and plant nutrients along a trophic gradient in the Florida Everglades. Soil Science Society of American Journal, 56, 1492-1499.

McCormick, P. V., Newman, S., Miao, S. L., Gawlik, D. E., Marley, D., Reddy, K. R., et al. (2001). Effects of anthropogenic phosphorus inputs on the Everglades. In J. W. Porter \& K. G. Porter (Eds.), The Everglades, Florida Bay, and coral reefs of the Florida keys: An ecosystem sourcebook ( pp 83-126). Boca Raton, FL: CRC.

McCormick, P. V., \& O’Dell, M. B. (1996). Quantifying periphyton responses to phosphorus in the northern Everglades: A synoptic approach. Journal of the North American Benthological Society, 15, 433-449.

McCormick, P. V., \& Stevenson, R. J. (1998). Periphyton as a tool for ecological assessment and management in the Florida Everglades. Journal of Phycology, 34, 726-733.

Newman, S., Grace, J. B., \& Koebel, J. W. (1996). The effects of nutrients and hydroperiod on mixtures of Typha domigensis, Cladium jamaisense, and Eleocharis interstincta: Implications for Everglades restoration. Ecological Applications, 6, 774-783.

Newman, S., McCormick, P. V., Miao, S. L., Laing, J. A., Kennedy, W. C., \& O'Dell, M. B. (2004). The effect of phosphorus enrichment on the nutrient status of a northern Everglades slough. Wetlands Ecology and Management, 12, 63-79.

Newman, S., Reddy, K. R., DeBusk, W. F., Wang, Y., Shih, G., \& Fisher, M. M. (1997). Spatial distribution of soil nutrients in a northern Everglades marsh: Water Conservation Area 1. Soil Science Society of American Journal, 61, 1275-1283.

Newman, S., Schuette, J., Grace, J. B., Rutchey, K., Fontaine, T., Reddy, K. R., et al. (1998). Factors influencing cattail abundance in the northern Everglades. Aquatic Botany, 60, 265-280.

Noe, G. B., Childers, D. L., \& Jones, R. D. (2001). Phosphorus biogeochemistry and the impact of phosphorus enrichment: Why is the Everglades so unique? Ecosystems, 4, 603-624.

Reddy, K. R., Wang, Y., DeBusk, W. F., Fisher, M. M., \& Newman, S. (1998). Forms of soil phosphorus in selected hydrologic units of the Florida Everglades. Soil Science Society of American Journal, 62, 1134-1147.

Reddy, K. R., Wang, Y., DeBusk, W. F., \& Newman, S. (1994). Physico-chemical properties of soils in the Water Conservation Area 3 (WCA-3) of the Everglades. Final Report, South Florida Water Management District, West Palm Beach, FL.

Reddy, K. R., White, J. R., Wright, A., \& Chua, T. (1999). Influence of phosphorus loading on microbial processes in the soil and water column of wetlands. In K. R. Reddy, G. A. O'Conner, \& C. L. Schelske (Eds.), Phosphorous biogeochemistry of subtropical ecosystems ( pp 249-273). New York, NY: Lewis Publishers.

Richardson, C. J., Ferrell, G. M., \& Vaithiyanathan, P. (1999) Nutrient effects on stand structure, resorption efficiency, and secondary compounds in Everglades sawgrass. Ecology, 80, 2182-2192.

Schloeder, C. A., Zimmerman, N. E., \& Jacobs, M. J. (2001). Comparison of methods for interpolating soil properties using limited data. Soil Science Society of American Journal, 65, 470-479.

Sklar, F., McVoy, C., VanZee, R., Gawlik, D. E., Tarboton, K., Rudnick, D., et al. (2001). Effects of altered hydrology on the ecology of the Everglades. In J. W. Porter \& K. G. Porter (Eds.), The Everglades, Florida Bay, and coral reefs of the Florida keys ( pp 39-82). Boca Raton, FL: CRC.

Sleutel, S., De Neve, S., Hofman, G., Boeckx, P., Beheydt, D., Van Cleemput, O., et al. (2003). Carbon stock changes and carbon sequestration potential of Flemish cropland soils. Global Change Biology, 9, 1193-1203.

Smith, S. M., Newman, S., Garrett, P. B., \& Leeds, J. A. (2001). Differential effects of surface and peat fire on soil constituents in a degraded wetland of the northern Florida Everglades. Journal of Environmental Quality, 30, 1998-2005.

South Florida Water Management District (1992). Surface water improvement and management plan for the Everglades. SFWMD, West Palm Beach, Florida, USA.

South Florida Water Management District and Florida Department of Environmental Protection (2004). Comprehensive everglades restoration plan annual report. http://www. evergladesplan.org/pm/cerp_annual_report.cfm.

Stober, Q. J., Thornton, K., Jones, R., Richards, J., Ivey, C., Welch, R., et al. (2001). South Florida ecosystem assessment: Phase I/II (Technical Report) - Everglades stressor interactions: Hydropatterns, eutrophication, habitat alteration, and mercury contamination. United States Environmental Protection Agency, Region 4 Science and Ecosystem Support Division 
and Water Management Division and Office of Research and Development, EPA 904-R-01-003.

U.S. Army Corps of Engineers (2005). Water conservation area 3: Decompartmentalization and sheet flow enhancementPart 1 [Online]. http://www.evergladesplan.org/pm/projects/ proj_12_wca3_1.cfm.

U.S. Department of the Interior (2005). Science plan in support of ecosystem restoration, preservation, and protection in South Florida. http://sofia.usgs.gov/publications/reports/ doi-science-plan/.

U.S. Environmental Protection Agency (1993). Methods for the determination of inorganic substances in environmental samples. Cincinnati, OH, USA: Environmental Monitoring Systems Lab.

Van Meirvenne Pannier, M. J., Hofman, G., \& Louwagie, G. (1996). Regional characterization of the long-term change in soil organic carbon under intensive agriculture. Soil Use and Management, 12, 86-94.

Zhang, C., \& McGrath, D. (2004). Geostatistical and GIS analyses on soil organic carbon concentrations in grassland of southeastern Ireland from two different periods. Geoderma, 119, 261-275. 